\title{
Impact implementation of law number 11 in 2012 concerning children's justice system for development of children
}

\author{
Sri Haryaningsih ${ }^{\left.1^{*}\right)}$, Titik Hariyati ${ }^{2}$ \\ ${ }^{1}$ Universitas Tanjungpura \\ ${ }^{2}$ Universitas Muhammadiyah Prof. Dr. HAMKA
}

\begin{tabular}{l} 
Article Info \\
\hline Article history: \\
Received Mar $09^{\text {th }}, 2021$ \\
Revised Apr $14^{\text {th }}, 2021$ \\
Accepted Apr $30^{\text {th }}, 2021$ \\
\hline
\end{tabular}

\section{Keyword:}

Law number 11 of 2012

Child criminal justice system

\begin{abstract}
Law number 11 of 2012 concerning the Child Criminal Justice System (UU SPPA) which has been published has brought a change in the paradigm of child crime with a prison nuance to a more child-friendly concept towards restorative justice. However, the phenomenon found in minors is still undergoing legal proceedings. Meanwhile, during the legal process, children are detained in detention centers and placed outside the Special Development Institution for Children (LPKA) and Temporary Child Placement Agency (LPAS). This research was conducted using a qualitative method to child prisoners in West Kalimantan Province. This research was conducted by conducting structured interviews and it carried the analysis of this research out with three lines, namely data reduction, data presentation and conclusion/verification. The findings of the study were helping to children in legal conflict in a fairly good range, even though help from expert advocates and the community had not been fully achieved. The reason it still places many children outside the LPKA is because there are no LPKA or LPAS in the district. Therefore, it is necessary to add LPKA or LPAS to pay attention to the needs of education, health and the needs of children of inmates so that it guarantees their growth and development.
\end{abstract}

(C) 2021 The Authors. Published by IICET.

This is an open access article under the CC BY-NC-SA license (https://creativecommons.org/licenses/by-nc-sa/4.0)

\section{Corresponding Author:}

Sri Haryaningsih,

Universitas Tanjungpura

Email: sri.haryaningsih@fisip.untan.ac.id

\section{Latar Belakang}

Anak adalah bagian yang tidak terpisahkan dari keberlangsungan hidup manusia (Luwiheningsih \& Lintang, 2014) dan keberlangsungan sebuah bangsa dan negara (Juliasari, 2020; Malisngorar, 2018; Marpaung \& Suryani, 2019; Putra, Budiartha, \& Dewi, 2020; Revita, 2017). Dalam konstitusi Indonesia, anak memiliki peran strategis yang secara tegas dinyatakan bahwa negara menjamin hak setiap anak atas kelangsungan hidup, tumbuh, dan berkembang serta atas perlindungan dari kekerasan dan diskriminasi (Bangsawan, 2018; Carter, 2019; Pratama, 2019; Santoso, 2014; Zuliah, 2017). Oleh karena itu, sebagai kepentingan terbaik bagi kelangsungan hidup umat manusia kepentingan terbaik bagi anak patut dihayati (Arliman, 2017; Carter, 2019; Juliasari, 2020; Luwiheningsih \& Lintang, 2014; Marpaung \& Suryani, 2019; Sania \& Utari, n.d). Konsekuensi dari ketentuan Pasal 28B Undang-Undang Dasar Negara Republik Indonesia Tahun 1945 perlu ditindaklanjuti dengan membuat kebijakan pemerintah yang bertujuan melindungi Anak (N. V. Ariani, 2014).

Anak perlu mendapat perlindungan dari dampak negatif perkembangan pembangunan yang cepat, arus globalisasi di bidang komunikasi dan informasi (Mubah, 2011; Pawestri \& Wahyuliana, 2019; Siwi, 2018), 
kemajuan ilmu pengetahuan dan teknologi, serta perubahan gaya. Selain itu, cara hidup sebagian orang tua yang telah membawa perubahansosial yang mendasar dalam kehidupan masyarakat yang sangat berpengaruh terhadap nilai danperilaku anak (Hariyadi \& Arliman, 2018; W. Setiawan, 2017). Penyimpangan tingkah laku atau perbuatan melanggar hukum yang dilakukan oleh anak, antara lain, disebabkan oleh faktor di luar diri anak tersebut (Purwanto \& Septrianto, 2004; Yuliartini, 2019).

Perlindungan hukum bagi anak dapat dilakukan sebagai upaya perlindungan hukum terhadap berbagai kebebasan dan hak asasi anak (Aji, 2010; Pangemanan, 2015; Prasetyo, 2020). Perlindungan terhadap anak ini juga mencakup kepentingan yang berhubungan dengan kesejahteraan anak (Hulu, 2018). Perlindungan anak yang berhadapan dengan hukum $(\mathrm{ABH})$ merupakan tanggung jawab bersama aparat penegak hokum (Abdurrachman, Sudewo, \& Permanasari, 2015; Ardian, 2015; Mareta, 2016; Purnama, Krisnan, \& Kurniaty, 2016). Tidak hanya anak sebagai pelaku, namun mencakup juga anak sebagai korban dan saksi. Aparat penegak hukum yang terlibat dalam penanganan $\mathrm{ABH}$ tidak hanya mengacu padaUndang- Undang Nomor 11 Tahun 2012 tentang Sistem Peradilan Pidana Anak atau peraturan perundang-undangan lainnya yang berkaitan dengan penanganan $\mathrm{ABH}$, namun lebih mengutamakan perdamaian daripada proses hukum formal yang mulai diberlakukan 2 tahun setelah UU SPPA diundangkan atau 31 Juli 2014 (Pasal 108 UU No. 11 Tahun 2012). Atas dasar itulah, alasan perubahan UU SPPA ini disebabkan beberapa hal berikut: pertama, kegagalan sistem peradilan pidana anak untuk menghasilkan keadilan; kedua, tingkat tindak pidana dan residivisme anak tidak mengalami penurunan; ketiga, proses peradilan gagal memperlakukan anak; keempat, pengadilan lebih banyak memanfaatkan pidana perampasan kemerdekaan (pidana penjara) daripada bentuk sanksi lainnya; dan kelima, pendekatan yang terlalu Legalistik (Diani Sedia Wati, 2014).

Dalam Pelaksanaan Sistem Peradilan Pidana Anak menggunakan pendekatan sistem, sehingga pihakpihak yang terlibat harus melaksanakan amanat undang-undang secara profesional dan bermartabat agar tidak terjadi kecurangan baik itu korupsi, kolusi dan nepotisme yang dapatmenggangu kinerja aparat penegak hukum misalnya dalam proses peradilan anak ini,. BAPAS memiliki peran yang cukup besar oleh karena peran BAPAS dari proses penyidikan, penuntutanserta pengadilan harus hadir dalam proses Diversi. Disisi lain faktor penilaian subjektif BAPAS juga cukup berpangaruh pada putusan hakim, oleh karena sebelum hakim menjatuhkan putusan terlebih dahulu mendengar dari pendapat BAPAS. Di samping peran yang demikian tidakmenuntup kemungkinan muncul tindakan-tindakan yang negatif semisal (suap). Tindakan lain adalah adanya pemaksaan agar terjadi proses perdamaian dari pihak Kepolisian dan Kejaksaanyang merupakan hasil pendekatan (suap) keluarga pelaku dengan pihak Kepolisan dan Kejaksaan.Tentunya ketika undang-undang telah berjalan akan nampak masalah-masalah yang menjadikelemahan dari Undang-undang SPPA yang harus dihindari oleh berbagai pihak sehinggaimplementasi pelaksanaan undang-undang ini sesuai tujuan pembentukan dan demi menciptakan keadilan dan kesejahteraan dalam masyarakat.

Data anak yang berhadapan dengan hukum dari Direktorat Jenderal Pemasyarakatan menunjukan bahwa tingkat kriminalitas serta pengaruh negatif penyalahgunaan narkotika, psikotropika, dan zat adiktif semakin meningkat (UU SPPA No.11 tahun 2012). Indonesia adalah salah satu negara yang pernah meratifikasi Konvensi Hak-Hak Anak (KHA) pada tahun 1990 yang telah disetujui oleh Majelis Umum PBB pada 20 November 1989. Dalam Pasal 4 KHA dinyatakan: Negara Peserta akan mengambil semua langkah legislatif, administrative dan lain sebagainya untuk pelaksanaan hak-hak yang diakui dalam konvensi. Selain itu dalamPasal 6 KHA dinyatakan: Negara Peserta mengakui bahwa setiap anak memiliki hak yang melekatatas kehidupan.

Satu dekade kemudian, tepatnya pada tahun 2001, Indonesia menyatakan komitmennya terhadap deklarasi Dunia Yang Layak Bagi Anak (A World Fit for Children). Sesuai dengan ketentuan Konvensi Hak Anak (Convention on the Rights of the Child) yang diratifikasi oleh pemerintah Indonesia melalui Keputusan Presiden Nomor 36 Tahun 1990, kemudian jugadituangkan dalam Undang - Undang Nomor 4 Tahun 1979 tentang Kesejahteraan Anak dan Undang - Undang Nomor 23 Tahun 2002 tentang Perlindungan Anak dan Undang-Undang Nomor 11 Tahun 2012 tentang Sistem Peradilan Pidana Anak yang kesemuanya mengemukakan prinsip-prinsip umum perlindungan anak, yaitu non diskriminasi, kepentingan terbaik bagi anak, kelangsungan hidup dan tumbuh kembang serta menghargai partisipasi anak (Ridwan Mansyur,2014).

Lapas II B yang berada di Kabupaten Ketapang, Kalimantan Barat merupakan Lapas untuk orang Dewasa akan tetapi yang terjadi sekarang telah ada anak-anak yang melakukan tindak pidana dan harus di tahan. Penangganan kasus yang melibatkan anak sebagai pelaku tindak pidana seharusnya ditangganin oleh lembaga pemasyarakatan khusus anak namun dari Kabupaten Ketapang belum dapat mengusahakannya sehingga penahanan bagi pelaku tindak pidana yang dilakukan oleh anak maupun dewasa disatukan dalam satu tempat yang sama, yaitu Lapas kelas II. Dalam Undang-Undang Nomor 11 tahun 2012 tentang sistem peradilan pidana anak meletakkan pondasi perlindungan anak dengan pendekatan keadilan restoratif (N. M. I. Ariani, Yuliartini, \& Mangku, 2020; N. V. Ariani, 2014), yaitu dalam penyelesaian perkara melibatkan pelaku, 
korban, keluarga pelaku/keluarga korban dan pihak lain yang terkait untuk bersama-sama mencari penyelesaian yang adil dengan menekankan pemulihan kembali pada keadaan semula dan bukan pembalasan dan keadilan restoratif tersebut diwujudkan melalui diversi, yaitu pengalihan penyelesaian perkara anak dari proses peradilan pidana ke proses diluar pengadilan pidana.

Anak dalam Lembaga Pemasyarakatan ditempatkan sebagai subyek dalam pembinaan dan bukan sebagai obyek pembinaan. Maksudnya, Anak merupakan manusia yang masih dihargai hak-haknya. Hal tersebut terkait dengan penggunaan sistem pemasyarakatan dalam Lembaga Pemasyarakatan. Berdasarkan hal demikian penelitian ini bertujuan untuk menganalisis dampak dari implementasi Undang-undang Nomor 11 Tahun 2012 tentang Sistem Peradilan Pidana Anak untuk perkembangan anak di Ketapang.

\section{Metode}

Jenis penelitian yang akan digunakan adalah kualitatif dalam bentuk deskriptif. Adapun metode analisis data yang digunakan dalam penulisan ini adalah metode analisis data secara kualitatif diantaranya melakukan reduksi data, triangulasi/penyajian data dan penarikan kesimpulan/verivikasi (Muin, 2013, 2014). Data yang sudah dianalisis ini selanjutnya akan disajikan dalam sebuah penulisan yang sistematis. Metode penelitian merupakan suatu cara ataupun teknik yang dipergunakan sebagai alat bantu untuk mengumpulkan data serta menganalisisnya agar diperoleh suatu kesimpulan guna mencapai tujuan penelitian. Analisis ini didahului dengan tinjauan dari beberapa pemangku kepentingan sambil mengumpulkan data tentang tindakan mereka, minat mereka, persepsi, perilaku pengalaman, pemikiran dalam kaitannya dengan sistem peradilan pidana anak di Ketapang. Key informan dalam penelitian ini yaitu anak yang dinarapidana, Kepala Lapas dan pegawai Dinas Sosial, LKPA Kalimantan Barat. Analisis dilakukan terkait dengan pengumpulan tulisan dan teks atau pengamatan langsung dari perilaku atau peristiwa yang terjadi, atau melalui wawancara mendalam dari para pemangku kepentingan ini. Sumber data atau informan penelitian, pemikirannya relevan dan mengetahui tujuan penelitian yang ingin dicapai. Sumber data dari wawancara mendalam.

\section{Hasil dan Pembahasan}

Masa-masa perkembangan anak adalah masa emas sekaligus masa paling penting. Untuk mencapai puncak perkembangan yang optimal, terutama pada periode perkembangan anak (Kertamuda, 2015).Definisi dari pertumbuhan adalah bertambahnya jumlah dan ukuran sel serta jaringan interselular (Dardjito, Sistiarani, \& Nurhayati, 2014; Nurti, Sari, \& Murtiyarini, 2020),yang juga berarti bertambah pula ukuran fisik dan struktur tubuh sang anak (Ngura \& Tia, 2018; Rini \& Wijaya, 2016; Zogara, 2017). Sedangkan,perkembangan anak, yakni menggambarkan adanya kenaikan pada kematangan fungsi individu (Ahmad Susanto, 2011). Pertumbuhan dan perkembangan anak sudah seharusnya diperhatikan dan dijaga dengan baik,karena dua hal tadi adalah indikator penting dalam mengukur status kesehatan anak (Fitriani \& Oktobriariani, 2017), yang nantinya akan berpengaruh pula pada kualitas hidup anak (Ahmad, 2017; Soetjiningsih, 2018). Sehingga dalam hal ini peran dari lingkungan terdekat anak khususnya sangat penting (Taubah, 2015).

Hambatan-hambatan yang timbul dalam mewujudkan implementasi Perlindungan hukum terhadap anak, yaitu sarana dan pra sarana yang terkait dengan proses penahanan (Sufriyatna \& Unisba, 2012). Dalam hal ini, khusus kasus anak, seorang anak yang berkonflik dengan hukum hanya dapat ditahan selama 15 hari. Hal demikian dikarenakan kasus anak ini ada di Kecamatan Manismata Kabupaten Ketapang Kalimantan barat, dimana ada keterbatasan waktu karena jarak antara Kabupaten Ketapang ke Kecamatan Manismata yang cukup jauh, dan Belum ada RPKA (Ruang Pelayananan Khusus Anak). Hal ini juga diperlukan dikarenakan berkaitan dengan mental anak yang terkadang sulit untuk diajak berkomunikasi.

Lapas II B yang berada di Kabupaten Ketapang, Kalimantan Barat merupakan Lapas untuk orang Dewasa akan tetapi yang terjadi sekarang telah ada anak-anak yang melakukan tindak pidana dan harus ditahan. Penanganan kasus yang melibatkan anak sebagai pelaku tindak pidana seharusnya ditangani oleh lembaga pemasyarakatan khusus anak namun dari Kabupaten Ketapang belum dapat mengusahakannya sehingga penahanan bagi pelaku tindak pidana yang dilakukan oleh anak maupun dewasa disatukan dalam satu tempat yang sama, yaitu Lapas kelas II.

\section{Komentar Responden 1 (Kepala Lapas)}

Berdasarkan wawancara dengan Responden 1

"karena keterbatasan sarana dan gedung lapas, walaupun antara napi dewasa dan anak di bedakan ruang gedung, tetapi tidak menutup kemungkinan adanya aktivitas dan interaksi antara anak dan napi dewasa, sehingga memengaruhi proses tumbuh kembang anak selama di lapas. Dan berdampak negatif bagi perkembangan anak tersebut" 
Implementasi perlindungan hak bagi Anak sebagai pelaku tindak pidana, khususnya pada tahap penyidikan pada praktiknya masih menemui hambatan yang mengakibatkan penerapannya tidak maksimal. Penempatan $\mathrm{ABH}$ dalam Lembaga Pemasyarakatan/Rutan Dewasa dengan berbagai latar belakang pertimbangannya memunculkan permasalahan yang potensial mendatangkan turunan permasalahan besar lainnya. Permasalahan utama ABH yang ditempatkan/dititipkan di Lapas Dewasa adalah terkait dengan pemenuhan hak-hak dasar anak. Anak tidak dapat di perlakukan sama dengan orang dewasa, dalam ukuran kecil kita yakin bahwa ada perbedaan antara pelanggar-pelanggar anak dengan orang yang sudah dewasa, sudah seharusnya anak mendapat perlakuan khusus dalam proses pemeriksaan di persidangan.

\section{Komentar Responden 2}

Berdasarkan wawancara dengan Responden 2 (Pegawai Dinas Sosial)

"Kenyataan di lapangan, khususnya di Provinsi Kalimantan Barat, masih terdapat tahanan dan napi anak yang ditempatkan di luar LPKA. Alasan yang ditemui adalah: tahanan anak yang sedang menunggu proses penetapan pengadilan dititipkan di Rutan karena di kabupaten tidak ada LPKS atau LPAS, dan NAPI anak ditempatkan di Lapas karena permintaan orang tua atau keluarga agar bisa sering berkunjung, dekat dengan rumah orang tuanya"

Sebenarnya anak memiliki hak untuk mendapatkan perlindungan baik secara hukum maupun sosial. Menurut Undang-Undang Sistem Peradilan Pidana Anak (UU SPPA), jika perilaku anak yang diduga melakukan tindak pidana, formal Terbitnya UU-SPPA sebagai bentuk upaya pemerintah dalam memberikan Perlindungan bagi pelaku, korban dan saksi tindak pidana berusia anak-anak. Pada ayat (2) huruf a dan huruf $\mathrm{b}$ anak-anak dibawah umur yang diduga menjadi pelaku tindak kriminal, maka penegak hukum wajib mengutamakan pendekatan keadilan restoratif (restorative justice) dan diversi (pengalihan kasus). bahkan diskresi (penghentian kasus).

Berdasarkan wawancara dengan Q1( Anak pelaku Kejahatan) diketahui bahwa yang masih berstatus pelajar SMA yang ditahan oleh pihak kepolisian, dan sudah di tetapkan sebagai tahan, di lapas kebupaten Ketapang, dengan kasus menyodomi anak guru, dan anak tersebut tidak merasa melakukan kejahatan seperti yang dituduhkan. Selanjutnya, berdasarakan wawancara lebih mendalam, diketahui bahwa orang tua anak tersebut memiki hutang dengan guru yang adanya dikatakan mengalami sodomi, Anak tersebut di jemput (ditahan di kantor polisi Kabu. Ketapang, untuk selamnjutnya di tahan di Lapas )

\section{Berdasarkan wawancara dengan Responden 1 mengatakan bahwa,}

"selama di lapas anak tersebut menunjukkan karakter dan sifat yang baik (sholat) dan tidak pernah melakukan tindakan yang buruk, dikarenakan rajin dan sering membantu di dalam lapas. Sebagai kepala lapas saya tidak memiliki kewenangan untuk menindak lanjuti keluhan anak tersebut, yang merasa tidak melakukan kejahatan, dikarenaan sudah adanya keputusan bahwa anak tersebut barsalah dan ditempatkan di lapas ini"

Penerapan diversi dan restorative justice sudah seharusnya lebih di utamakan bagi anak pelaku tindak pidana (Sahetapy, 2012), sekalipun mereka melakukan kejahatan seksual dan bukan menekankan pada pemberian hukuman pidana (Kaimuddin, 2016; Pradityo, 2016; Purwanti, 2019; Yusnita, 2018). Tindakan diversi dapat dilakukan oleh pihak kepolisian, kejaksaan, pihak pengadilan maupun pembina lembaga pemasyarakatan (Sari, 2013; D. A. Setiawan, 2017). Penerapan diversi di semua tingkatan ini diharapkan mengurangi efek negatif keterlibatan anak dalam proses peradilan tersebut. Hal ini dilaksanakan dengan harapan anak pelaku tindak pidana kejahatan seksual dapat memperbaiki diri dan selanjutnya dibina oleh pihak yang berwenang agar kedepannya anak tersebut bisa menjadi lebih baik. UU SPPA secara tegas, mengamanatkan bahwa pada anak yang berusia dibawah 12 tahun, tidak memiliki kewajiban untuk menempati penjara. Proses diversi, dan restorative justice, dapat dilakukan jika tindakan yang dilakukan mendapatkan ancaman dibawah 7 tahun, dan bukan merupakan pengulangan tidak pidana.

Bahkan proses diversi ini dapat dilakukan saat anak berada pada proses penyidikan, penuntutan atau sebelum persidangan (UU SPPPA pasal 7), sehingga anak terhindar dari penahanan dan pemenjaraan. Berbeda halnya pada anak yang berusia diatas 12 tahun, tindakannya diancam lebih dari 7 tahun dan berupa pengulangan, maka anak akan menjalankan proses hukum. Kecuali anak yang telah melampaui batas umur 18 (delapan belas) tahun, tetapi belum mencapai umur 21 (dua puluh satu) tahun, maka anak harus diajukan ke sidang Anak. Proses Diversi sangat melindungi anak dari perampasan hak-hak anak (Pangalila, 2018), karena bertujuan agar anak mencapai perdamaian antara korban dan anak pelaku, menyelesaikan perkara Anak di luar proses peradilan. Selanjutnya juga menghindarkan anak dan perampasan kemerdekaan, mendorong masyarakat untuk berpartisipasi dan menanamkan tanggungjawab terhadap anak.

Dalam masyarakat yang sudah mempunyai hukum tertulis, biasanya usia anak ditetapkan dalam suatu batasan umur tertentu. Di tiap-tiap Negara tidak ada yang sama dalam menentukan batas usia, misalnya di Inggris batas usia tahun, Denmark 15 tahun. Batasan usia anak tersebut sangat penting dalam proses penyelesaian perkara pidana, karena hal tersebut akan di pergunakan sebagai tolak ukur untuk mengetahui 
seseorang yang diduga telah melakukan tindak pidana termasuk kategori anak atau bukan, yang nantinya akan di jadikan pandangan oleh penegak hukum dalam menentukan peraturan perundang-undangan mana yang akan dipergunakan sebagai pedoman dalam penanganan perkara pidana yang telah dilakukan.

\section{Berdasarkan wawancara dengan Q2 ( Anak pelaku Kejahatan) diketahui bahwa}

selama di lapas anak tidak mendapat hak dasar pendidikan dan hak mendapat perlindungan dan bantuan hokum, hanya sebatas kebutuhan makanan, air bersih, pelayanan kesehatan. Belum ada program pengembangan yang dapat mengembangkan minat dan bakat anak.

Perlindungan terhadap anak yang berhadapan dengan hukum dalam proses peradilan pidana selama ini seringkali diposisikan sebagai objek dan cendrung merugikan anak. Dalam perkara anak adakalanya anak sebagai pelaku, korban dan saksi dalam suatu tindak untuk itu perlu penanganan yang serius dan harus dilakukan oleh pejabat yang memahami masalah anak. Dengan demikian anak akan terbebas dari proses pemenjaraan dan penahanan. Apabila anak pelaku pencabulan masuk proses hukum, maka anak harus melalui serangkaian proses, mulai dari penangkapan, penyidikan dan penyelidikan, penuntutan sampai akhirnya persidangan. Bentuk putusan yang diterima anak dapat berupa kembali ke orang tua, mendapatkan rehabilitasi pada Lembaga Penyelenggara Kesejahteraan Sosial atau LPKS, atau diputus pidana penjara sebagai seorang narapidana anak. Tentu saja proses pemidanaan anak sangat tidak diharapkan, karena setidaknya akan mempengaruhi pada kehidupan anak selanjutnya. Meski anak diputus untuk mendapatkan pembinaan dari lembaga sosial namun anak sudah terlanjur menjadi penghuni rumah tahanan, dengan berbagai pengalaman dan kehidupan selama dalam sel tahanan.

Penahanan anak bisa di Rumah Tahanan (Rutan) khusus anak, atau Rutan dewasa, jika wilayah hukumnya tidak terdapat Rutan anak, atau di ruang tahanan kantor Kepolisian setempat. Anak akan menjalankan penahanan minimal selama 20 hari berada di sel tahanan. Kondisi tersebut tentunya akan sangat mempengaruhi perkembangan psikologis anak. Masih adanya anak-anak berada dalam psoses hukum yang selanjutnya mendapatkan vonis penjara sebagai narapidana anak, tentunya berlawanan dengan semangat bahwa pemenjaraan anak sebagai "last resort", dan pergeseran paradigma dalam hukum pidana tentang keadilan dari Retributive Justice ke Restorative Justice dan Diversi. Berdasarkan hal tersebut, maka melalui tulisan ini akan dipaparkan anak-anak pelaku kejahatan seksual yang menjalankan proses hukum.

Pada kasus di Kabupaten Ketapang ada anak yang berusia dibawah 16 tahun, bahkan ada diantaranya yang sudah memiliki anak sebagai hasil hubungan diluar nikah. Kondisi ini menunjukkan bahwa anak tersebut telah melakukan aktivitas seksual secara dini. Hasil penelitiannya menemukan bahwa faktor yang berperan pada anak yang melakukan aktivitas seksual dini karena pubertas lebih awal, kemiskinan, prestasi akademis yang buruk, tidak memiliki tujuan akademis dan karier (Irmayani, 2019), memiliki pengalaman pelecehan seksual atau penelantaran oleh orang tua. Berdasarkan kasus diatas jelas menunjukkan bahwa putus sekolah sebagai gambaran tidak memiliki tujuan akademis untuk masa depannya. Masih kuatnya anggapan bahwa perilaku seksual pada anak-anak dibawah umur, merupakan perilaku yang melawan norma yang berlaku di masyarakat, maka konsekuensi pelaku harus dihukum.

\section{Kasus Q2}

Anak tersebut tetap dilaporkan ke polisi dan ditahan, walaupun anak tersebut bersedia untuk bertanggung jawab terhadap kehamilan korban, dan sebenarnya kasus anak berkonflik hukum, berusia dibawah 12 tahun memiliki hak untuk mendapatkan diversi, akan tetapi dikarenakan tidak adanya bantuan hokum maupun badan yang perlindungan anak di daerah untuk anak tersebut, maka anak itu tidak mendapatkan diversi, antara pikah korban dan anak sebagai pelaku kejahatan.

Meski sebenarnya pelaku merupakan korban dari kondisi di dalam keluarga atau lingkungan yang kurang mendukung bagi anak, sehingga anak terjerumus kedalam perilaku asusila. Anak dilaporkan oleh orang tua korban, ke Kepolisian terdekat, sehingga anak harus mempertanggung-jawabkan atas perbuatannya. Sebagai pelaku yang disangkakan melakukan pelecehan seksual maka anak harus dihukum. Kemudian anak akan melalui proses hukum dan merasakan kehidupan dalam Rumah Tahanan, minimal 20 hari. Selama proses penahanan mereka berada dalam sel berukuran $2 \times 3$ meter dengan jumlah penghuni 5-6 orang, dengan kamar dan toilet di dalam ruangan. Mereka tidur berdempet-dempetan. Kesehariannya hanya menunggu sampai proses persidangan, tanpa ada kegiatan. Untuk mengisi waktu luang, mereka hanya berinteraksi dengan sesama teman dalam sel, kadang-kadang ada kesempatan untuk berinteraksi dengan penghuni lain yang ada di Lapas/Rutan terutama saat sembahyang, sehingga perasaan jenuh, sedih, penyesalan, kesepian sering timbul selama mereka ditahan.

LPKA Provinsi Kalimantan Barat melaksanakan pembinaan selain menjalani masa tahanan juga dibina guna memperbaiki diri dan dapat menguasai bidang-bidang tertentu supaya kelak setelah masa hukuman selesai mempunyai bekal ketrampilan, dan inilah merupakan tanggung-jawab yang disandang oleh LPKA 
dalam hal mempersiapkan resosialisasi anak pelaku kejahataa, yang merupakan peranan Lembaga Pembinaan Khusus Anak dalam mempersiapkan resosialisasi anak pelaku kejahatan adalah memberikan pembinaan bagi anak pelaku kejahatan.

\section{Kementar R 3 (LPKA Provinsi Kalimantan Barat) Pembinaan tersebut meraneka ragam seperti yang diungkapkan $R 3$ mengatakan :}

"Jika membahas tentang Implementasi Kebijakan Perlindungan Anak Pada Lembaga Pembinaan Khusus Anak Provinsi Kalimantan Barat sangat kompleks ya, dikarenakan berbagai keterbatasan yang ada, sarana, prasarana maupun sumber daya manusia yang ada, tapi LPKA itu memiliki peranan yang sangat penting, merupakan tempat bagi anak-anak agar selama menjalani proses pembinaan terpisahkan dari narapidana dewasa dan memberikan berbagai pembinaan bagi anak pelaku kejahatan".

Berdasarkan pembahasan sebelumnya diatas, Lembaga Pembinaan Khusus Anak Provinsi Kalimantan Barat, seharusnya selain memberikan pembinaan kepribadian yang memulihkan harga diri anak pelaku kejahatan, juga berusaha menunjukkan pada anak pelaku kejahatan bahwa diri mereka masih memiliki potensi produktif. Anak pelaku kejahatan disadarkan bahwa setelah masuk ke dalam LPKA dan menjadi anak pelaku kejahatan bukan berarti mereka tidak dapat melakukan sesuatu lagi. Anak pelaku kejahatan sebagai seseorang yang membutuhkan bantuan karena kelemahan yang dimilikinya. Sehingga ini menjadi tanggung jawab LPKA dalam membekali anak pelaku kejahatan agar kelak setelah bebas mereka tetap bisa melanjutkan hidupnya secara mandiri.

Pengalaman menunjukkan bahwa umumnya anak berkonflik hukum adalah mereka yang berasal dari keluarga yang menghadapi masalah ekonomi maupun sosial. Masalah mulai muncul saat keluarga mengalami kemiskinan dan/atau disfungsi keluarga. Sehingga tekanan teman sebaya dalam kaitannya dengan perilaku melanggar hukum atau ajakan berbuat cabul menjadi daya tarik tersendiri. Pengaruh teman sebaya yang sama-sama putus sekolah atau kurang memiliki kegiatan positif, telah menjerumuskan anak berhadapan dengan hukum. Proses hukum yang harus dijalani anak mulai dari dari penahanan, penyidikan, penyelidikan, penuntutan dan putusan, minimal selama 150 hari. Bagi anak berusia dibawah 12 tahun dapat di putus pengadilan untuk memperoleh pembinaan di LPKS, sedangkan anak-anak diatas usia 12 tahun, dapat diputus untuk mendapatkan pembinaan dalam Penjara (LP anak) atau pembinaan di LPKS. Sebenarnya kasus anak berkonflik hukum, berusia dibawah 12 tahun memiliki hak untuk mendapatkan diversi, akan tetapi pandangan masyarakat terhadap anak sebagai pelaku pencabulan dianggap dapat meresahkan masyarakat, dan permintaan ganti rugi terhadap keluarga pelaku yang melampaui kemampuannya, sehingga mengharuskan anak menjalani proses hukum.

Namun demikian anak masih memiliki kesempatan untuk mendapatkan diversi, yang dapat diperoleh saat penyidikan di Kepolisian, penuntutan di kejaksaan, dan putusan peradilan oleh Hakim. Namun demikian anak telah melampaui penahanan, baik di Rutan maupun di penjara atau LP, dengan status sebagai tahanan. Pemberlakuan diversi terhadap anak-anak pada semua tingkatan, bertujuan untuk mengurangi efek negatif (negative effect) dari keterlibatan anak selama proses peradilan. Hasil penelitian menunjukkan bahwa setelah anak ditahan dan dipenjara, mereka merasakan penyesalan, serta tidak senang berada di penjara karena tidak adanya lagi kebebasan, bahkan merasa terbuang. Belum lagi stigma sebagai anak pidana, setidaknya akan mempengaruhi kehidupan psikologis anak.

Implementasi perlindungan hak bagi Anak sebagai pelaku tindak pidana, khususnya pada tahap penyidikan pada praktiknya masih menemui hambatan yang mengakibatkan penerapannya tidak maksimal. Bila diklasifikasikan permasalahan yang menghambat implementasi perlindungan hak bagi anak sebagai pelaku tindak pidana, LPKA belum tersebar di seluruh tingkat kota/kabupaten di Kalimatan Barat sehingga menghambat akselerasi penyidik dalam penanganan kasus Anak, belum semua kota/kabupaten di Kalimatan Barat mempunyai lembaga penyelenggara kesejahteraan sosial (LPKS) dan lembaga penempatan anak sementara (LPAS) sehingga Anak terkadang ditempatkan di ruang tahanan Kepolisian yang tidak memenuhi kualifikasi sesuai UU SPPA dan sangat dimungkinkan tidak terpenuhinya hak Anak selama proses penyidikan. Pemenuhan hak-hak anak yang berhadapan dengan hukum di Kabupaten Ketapang, hanya sebatas kebutuhan makanan, air bersih, pelayanan kesehatan. Selanjutnya, belum ada program pengembangan yang dapat mengembangkan minat dan bakat anak untuk mengisi waktu penahanan. Pola pembinaan masih disamakan dengan pola pembinaan terhadap tahanan dewasa. Hambatan eksternal lainnya adalah kesadaran masyarakat tentang perlindungan hak Anak yang masih relatif minim, sehingga masyarakat masih melihat Anak dari sudut pandang sosial sebagai pelaku kejahatan yang harus diberi sanksi. 


\section{Simpulan}

Implementasi Undang - Undang No.11 Tahun 2012 Tentang Sistem Peradilan Anak Terhadap Perkembangan Tumbuh Kembang Anak Di Kabupaten Ketapang belum terlaksana secara baik. Hal tersebut dapat disebabkan karena kurangnya sosialisasi tentang Sistem Peradilan Pidana Anak yang baru, aparat penegak hukum yang mempunyai kualifikasi sebagai penyidik anak masih kurang, atau hakim anak yang masih sedikit jumlahnya, serta kemungkinan belum siapnya sarana dan prasarana yang diperlukan dalam penerapan sistem peradilan pidana anak secara utuh. Implementasi perlindungan hak bagi Anak sebagai pelaku tindak pidana, khususnya pada tahap penyidikan pada praktiknya masih menemui hambatan yang mengakibatkan penerapannya tidak maksimal. Bila diklasifikasikan permasalahan yang menghambat implementasi perlindungan hak bagi anak sebagai pelaku tindak pidana. LPKA belum tersebar di seluruh tingkat kota/kabupaten di Kalimatan Barat sehingga menghambat akselerasi penyidik dalam penanganan kasus Anak. Hal demikian karena belum semua kota/kabupaten di Kalimatan Barat mempunyai lembaga penyelenggara kesejahteraan sosial (LPKS) dan lembaga penempatan anak sementara (LPAS). Sehingga Anak terkadang ditempatkan di ruang tahanan Kepolisian yang tidak memenuhi kualifikasi sesuai UU SPPA dan sangat dimungkinkan tidak terpenuhinya hak Anak selama proses penyidikan. Hambatan eksternal lainnya adalah kesadaran masyarakat tentang perlindungan hak Anak yang masih relatif minim, sehingga masyarakat masih melihat Anak dari sudut pandang sosial sebagai pelaku kejahatan yang harus diberi sanksi.

\section{Referensi}

Abdurrachman, H., Sudewo, F. A., \& Permanasari, D. I. (2015). Model Penegakan Hukum Anak yang Berhadapan dengan Hukum dalam Proses Penyidikan. Pandecta: Jurnal Penelitian Ilmu Hukum (Research Law Journal), 10(2), 167-179.

Ahmad, D. N. (2017). Membangun Komunikasi dan Pendidikan Berkarakter dalam Keluarga dalam Pengenalan Awal Organ Seksual pada Anak. BIOEDUKASI, 8(2), 125-133.

Ahmad Susanto, M. P. (2011). Perkembangan Anak Usia Dini: pengantar dalam berbagai aspeknya: Kencana.

Aji, Y. P. (2010). Perlindungan Hukum terhadap Penelantaran Anak oleh Orang Tua Angkatnya. Universitas Airlangga.

Ardian, M. (2015). Analisis Penerapan Diversi terhadap Anak yang Melakukan Tindak Pidana Perkosaan. Universitas Lampung.

Ariani, N. M. I., Yuliartini, N. P. R., \& Mangku, D. G. S. (2020). Implementasi Undang-Undang Nomor 11 Tahun 2012 tentang Sistem Peradilan Pidana Anak Terhadap Curanmor yang dilakukan Oleh Anak di Kabupaten Buleleng (Studi Kasus Perkara Nomor: B/346/2016/Reskrim). Jurnal Komunitas Yustisia, 2(2), 100-112.

Ariani, N. V. (2014). Implementasi Undang-Undang Nomor 11 Tahun 2012 tentang sistem peradilan pidana anak dalam upaya melindungi kepentingan anak. Media Hukum, 21(1), 16.

Arliman, L. (2017). Reformasi Penegakan Hukum Kekerasan Seksual Terhadap Anak Sebagai Bentuk Perlindungan Anak Berkelanjutan. Kanun Jurnal Ilmu Hukum, 19(2), 305-326.

Bangsawan, M. (2018). Pendidikan Karakter Terhadap Anak Jalanan Sebagai Korban Eksploitasi Anak di Kota Surakarta, Indonesia.

Carter, J. (2019). Pelaksanaan Peraturan Pemerintah Nomor 48 Tahun 2008 Tentang Pendanaan Pendidikan Terkait Pungutan Sekolah pada Sekolah Menengah Atas Negeri di Medan.

Dardjito, E., Sistiarani, C., \& Nurhayati, S. (2014). Deteksi pertumbuhan dan perkembangan balita melalui penggunaan buku KIA. Kesmas Indonesia: Jurnal Ilmiah Kesehatan Masyarakat, 6(3), 166-175.

Fitriani, I. S., \& Oktobriariani, R. R. (2017). Stimulasi, Deteksi dan Intervensi Dini Orang Tua terhadap Pencegahan Penyimpangan Pertumbuhan dan Perkembangan Anak Balita. Indonesian Journal for Health Sciences, 1(1), 1-9.

Hariyadi, H., \& Arliman, L. (2018). Peran Orangtua Dalam Mengawasi Anak Dalam Mengakses Media Internet Untuk Mewujudkan Perlindungan Hak Anak. Soumatera Law Review, 1(2), 267-281.

Hulu, K. I. (2018). Analisis Yuridis terhadap Perlindungan Anak Angkat Dikaitkan dengan Peraturan Pemerintah Nomor 54 Tahun 2007 tentang Pengangkatan Anak. Jurnal Education and Development, 5(1), 75-75.

Irmayani, N. R. (2019). Problematika Penanganan terhadap Anak Pelaku Tindak Kekerasan Seksual Selama Menjalankan Proses Hukum (Kasus di Provinsi Kalimantan Barat). Sosio Konsepsia, 8(3), 287-302.

Juliasari, T. (2020). Kendala Penyelesaian Perkara Anak Melalui Diversi (Studi Kasus Putusan Nomor PUT. NO. 1/PIDSUS-Anak/2015 Pengadilan Negeri Mempawah). Jurnal Fatwa Hukum, 3(3).

Kaimuddin, A. (2016). Perlindungan Hukum Korban Tindak Pidana Pencurian Ringan Pada Proses Diversi Tingkat Penyidikan. Arena Hukum, 8(2), 258-279. 
Kertamuda, M. A. (2015). Golden Age-Strategi Sukses membentuk Karakter Emas pada Anak: Elex Media Komputindo.

Luwiheningsih, T., \& Lintang, G. (2014). Perlindungan Hukum Terhadap Anak yang Berhadapan dengan Hukum. Universitas Dr. Soetomo, Surabaya.

Malisngorar, J. (2018). Perlindungan Hukum terhadap Anak Korban Perdagangan Orang. Universitas Airlangga, Surabaya.

Mareta, J. (2016). Mekanisme Penegakan Hukum Dalam Upaya Perlindungan Hak Kelompok Rentan (Anak Dan Perempuan)(Mechanism of Law Enforcement in Protecting the Rights of Vulnerable Group)(Child and Woman). Jurnal HAM, 7(2), 141-155.

Marpaung, R., \& Suryani, D. E. (2019). Perlindungan Hukum terhadap Anak Sebagai Korban Pencabulan Dikaitkan dengan Undang-Undang No 35 Tahun 2014 Tentang Perlindungan Anak (Studi Kasus Putusan Nomor 778/Pid. B/2014/PN-Lbp-LD). Ius Civile: Refleksi Penegakan Hukum dan Keadilan, 3(2).

Mubah, A. S. (2011). Strategi meningkatkan daya tahan budaya lokal dalam menghadapi arus globalisasi. Jurnal Unair, 24(4), 302-308.

Muin, A. (2013). Penguatan Karakter Melalui Pendidikan Islam di TK Mawaddah Kota Banjarmasin. Edukasi: Jurnal Penelitian Pendidikan Agama dan Keagamaan, 11(2).

Muin, A. (2014). Efektifitas Pembinaan Madrasah Diniyah Di Kota Yogyakarta. Edukasi: Jurnal Penelitian Pendidikan Agama dan Keagamaan, 12(3).

Ngura, E. T., \& Tia, Y. W. (2018). Stimulasi Tumbuh Kembang Anak Usia Dini: Menumbuhkan Karakter Anak Sejak Usia Dini. Paper presented at the 2nd Annual Proceeding, .

Nurti, T., Sari, L. A., \& Murtiyarini, I. (2020). Faktor-Faktor yang Berhubungan dengan Risiko Gagal Tumbuh Pada Anak Usia> 6-24 Bulan di Puskesmas Kenali Besar Kota Jambi Tahun 2016. Jurnal Ilmiah Universitas Batanghari Jambi, 20(3), 961-966.

Pangalila, A. E. (2018). Sistem Diversi Terhadap Anak Sebagai Pelaku Tindak Pidana Dalam Sistem Peradilan Dikaitkan Dengan Perlindungan Hak Asasi Manusia. Lex Et Societatis, 6(4).

Pangemanan, J. B. (2015). Pertanggungjawaban Pidana Anak Dalam Sistem Peradilan Pidana Indonesia. Lex Et Societatis, 3(1).

Pawestri, A., \& Wahyuliana, I. (2019). Pendekatan Moral sebagai Upaya Perlindungan Hak Anak dari Dampak Perkembangan Teknologi. Simposium Hukum Indonesia, 1(1), 437-449.

Pradityo, R. (2016). Restorative Justice dalam Sistem Peradilan Pidana Anak. Jurnal Hukum dan Peradilan, 5(3), 319-330.

Prasetyo, A. (2020). Perlindungan Hukum Bagi Anak Pelaku Tindak Pidana. Mizan: Jurnal Ilmu Hukum, 9(1), 51-60.

Pratama, I. A. (2019). Penyelesaian Kasus Tindak Pidana terhadap Anak Pelaku Pencurian dengan Cara Diversi di Kepolisian Sektor Baamang Sampit. Universitas Islam Sultan Agung, Jawa Tengah.

Purnama, P. C., Krisnan, J., \& Kurniaty, Y. (2016). Pelaksanaan Diversi ditingkat Pengadilan Berdasarkan Undang-Undang Nomor 11 Tahun 2012 tentang Sistem Peradilan Pidana Anak. Varia Justicia, 12(2), 222234.

Purwanti, S. (2019). Penerapan Diversi dalam Tingkat Pengadilan terhadap Anak Pelaku Tindak Pidana Pencabulan. Hermeneutika: Jurnal Ilmu Hukum, 3(1).

Purwanto, P., \& Septrianto, S. (2004). Pengaturan Tindak Pidana Anak Menurut KUHP dan UU No. 3 Tahun 1997. Majalah Kajian Hukum, 1410-7961.

Putra, I. M. D., Budiartha, I. N. P., \& Dewi, A. S. L. (2020). Perlindungan Hukum Anak Nakal dalam Penjatuhan Sanksi Pidana. Jurnal Preferensi Hukum, 1(2), 83-87.

Revita, A. (2017). Penegakan HAM Anak di Indonesia (Tinjauan Berdasarkan UU Nomor 35 Tahun 2014 Tentang Perlindungan Anak). Universitas Islam Negeri Alauddin Makassar, Makassar.

Rini, S., \& Wijaya, A. P. (2016). Implementasi deteksi gangguan pertumbuhan perkembangan balita (usia 1-5 tahun) dengan stimulasi, deteksi dan intervensi dini tumbuh kembang (SDIDTK) di posyandu kucai Kelurahan Teluk Kabupaten Banyumas. Bidan Prada: Jurnal Publikasi Kebidanan Akbid YLPP Purwokerto, $7(1)$.

Sahetapy, E. L. (2012). Restorative Justice Dalam Wujud Diversi, Kasus Anak Yang Berkonflik Dengan Hukum. from repository.ubaya.ac.id

Sania, G. A. T., \& Utari, A. A. S. (n.d). Perlindungan Hukum terhadap Anak sebagai Korban Tindak Pidana Pemerkosaan. Kertha Wicara: Journal Ilmu Hukum, 9(3), 1-15.

Santoso, W. (2014). Perlindungan Hukum Terhadap Anak Dari Tindakan Kekerasan. Lex Crimen, 3(4).

Sari, M. A. C. M. (2013). Diversi dalam Sistem Peradilan Pidana Anak di Indonesia. Jurnal Magister Hukum Udayana, 2(1), 44093. 
Setiawan, D. A. (2017). Efektivitas Penerapan Diversi terhadap Penanganan Anak yang Berhadapan dengan Hukum dalam Peradilan Pidana Anak Sesuai Undang-Undang Republik Indonesia Nomor 11 Tahun 2012 tentang Sistem Peradilan Pidana Anak. DiH: Jurnal Ilmu Hukum, 13(26), 231-242.

Setiawan, W. (2017). Era digital dan tantangannya. Paper presented at the Seminar Nasional Pendidikan. Retrieved from eprints.ummi.ac.id

Siwi, P. P. A. (2018). Tindakan Pencabulan yang dilakukan Anak terhadap Anak dalam Putusan No. 10/Pid. SusAnak/2017/PN. Bjn (Studi Kasus pada Pengadilan Negeri Bojonegoro). Universitas Bojonegoro.

Soetjiningsih, C. H. (2018). Perkembangan Anak Sejak Pembuahan Sampai dengan Kanak-Kanak Akhir: Seri Psikologi Perkembangan: Prenada Media.

Sufriyatna, R., \& Unisba, A. F. H. (2012). Perlindungan Hukum Terhadap Penerapan Hak-hak Terdakwa Anak Dalam Sistem Peradilan Pidana Anak Dihubungkan Dengan Undang-undang Nomor 3 Tahun 1997 Tentang Pengadilan Anak. Syiar Hukum, 15(1), 289-303.

Taubah, M. (2015). Pendidikan Anak dalam Keluarga Perspektif Islam. Jurnal Pendidikan Agama Islam (Journal of Islamic Education Studies), 3(1), 109-136.

Yuliartini, N. P. R. (2019). Kenakalan Anak dalam Fenomena Balapan Liardi Kota Singaraja dalam Kajian Kriminologi. Jurnal Advokasi, 9(1), 31-43.

Yusnita, L. (2018). Analisis Penerapan Prinsip Restorative Justice Dalam Penyelesaian Perkara Tindak Pidana Lalu Lintas. Skripsi, Fakultas Hukum: Universitas Hasanuddin, Makasar.

Zogara, A. U. (2017). Pengetahuan Ibu Tentang Penggunaan KMS Berhubungan Dengan Pertumbuhan Anak 6-24 Bulan. CHMK Nursing Scientific Journal, 1(1).

Zuliah, A. (2017). Urgensi Pelaksanaan Diversi dan Keadilan Restoratif Pasca Pemberlakukan Undangundang No 11 Tahun 2012 Tentang Sistem Peradilan Pidana Anak. Warta Dharmawangsa(51). 